\title{
The rapid recovery of loss of small and taste with doxycycline in COVID-19
}

\author{
Habibullah Aktaş ${ }^{1}$, Gökşen Ertruğrul ${ }^{1}$, Hikmet Demirkol ${ }^{1}$, and Harun Erol $^{1}$ \\ ${ }^{1}$ Karabuk University
}

February 1, 2021

\begin{abstract}
Covid-19 is a viral multisystemic disease that caused a worldwide pandemic in 2020 (1). Due to the rapidly increasing number of cases, all medical doctors in many countries of the world, regardless of their specialties, took part in the treatment of COVID-19 patients.It has been reported that a significant number of COVID - 19 patients appear to have loss of smell (anosmia) and taste (dysgesuia). We observed that the loss of taste and smell improved in 2-5 days with doxycycline treatment in 4 covid-19 patients .Doxycycline, whose effectiveness against Covid-19 has been shown by various studies, can be a considerable therapeutic option, regarding that it may also improve loss of taste and smell that are very distressing symptoms. We contribute to this recommendation with four cases we present in this article.
\end{abstract}

\section{Hosted file}

The rapid recovery of loss of small and taste with doxycycline in COVID-19.pdf available at https://authorea.com/users/393058/articles/506790-the-rapid-recovery-of-loss-of-smalland-taste-with-doxycycline-in-covid-19

\section{Hosted file}

Title page. The rapid loss of smell and taste with doxycycline in COVID-19 patients.pdf available at https://authorea.com/users/393058/articles/506790-the-rapid-recovery-of-lossof-small-and-taste-with-doxycycline-in-covid-19 